\title{
Numbers of steroidogenic luteal cells in Booroola Merino ewes
}

\author{
G. D. Niswender*, K. P. McNatty†, P. Smith $\ddagger$ K. D. Niswender*, \\ C. E. Farin* $\ddagger$ and H. R. Sawyer* \\ * Animal Reproduction Laboratory, Department of Physiology, Colorado State University, \\ Fort Collins, CO 80523, USA; and \\ †Ministry of Agriculture and Fisheries, Wallaceville Animal Research Centre, Upper Hutt, \\ New Zealand
}

\begin{abstract}
Summary. In Exp. 1 ovulation rates, plasma concentrations of progesterone, mean individual and total CL weights were determined on Days 4, 10 and 12 after oestrus of Booroola Merino ++ ewes and FF ewes. Mean ovulation rates ranged from 1.5 to 1.8 in ++ ewes and from 5.3 to 6.2 in FF ewes $(P<0.01)$. There were no differences in plasma concentrations of progesterone or total luteal weight between the two groups on any of the days studied. Individual CL were smaller $(P<0.01)$ in FF ewes than in ++ ewes. In Exp. 2 the numbers of luteal cells in CL collected from $5++$ and 5 FF ewes on Day 10 of the oestrous cycle were morphometrically determined. The CL from FF ewes were smaller $(P<0.01)$ and had fewer total steroidogenic cells $(P<0.01)$, fibroblasts $(P<0.01)$, and capillary endothelial cells and pericytes $(P<0.05)$. However, the luteal cell volume density, number of cells/g tissue, average cell diameter or average cell volume was not different between the two groups of ewes for any cell type studied. It is concluded that the 5-6 CL in FF ewes function in an identical fashion to the $1-2 \mathrm{CL}$ in ++ ewes.
\end{abstract}

Keywords: Booroola ewes; luteal cells; steroidogenesis

\section{Introduction}

The corpus luteum in a variety of species including sheep, cattle, pigs and primates contains two distinct steroidogenic cell types (for reviews see, Niswender $e t$ al., 1985; O'Shea, 1987). These cell types have been designated small and large luteal cells and differ both in structure and biochemical properties (O'Shea et al., 1979, 1980; Fitz et al., 1982; Hoyer \& Niswender, 1985).

It has been suggested that small luteal cells in the ewe and cow are derived from the thecal layer of the preovulatory follicle while large cells originate from the granulosa layer (Deane et al., 1966; O'Shea et al., 1980). These suggestions were based on morphological changes in the follicular cell types and the respective luteal cell types, particularly during the periovulatory period. Using monoclonal antibodies specific for thecal and granulosa cell membrane antigens, Alila \& Hansel (1984) concluded that small luteal cells are derived exclusively from the theca interna of the preovulatory follicle. Furthermore, their data can be interpreted to indicate that small luteal cells develop into large luteal cells as the oestrous cycle progresses. Although controversial, the data of Alila \& Hansel (1984) support the hypothesis originally advanced by Donaldson \& Hansel (1965) that small luteal cells convert to large luteal cells, possibly under the influence of luteinizing hormone (LH; Farin et al., 1988). Results of experiments involving dissociated luteal cells and morphometric

$\$$ Present address: Department of Animal Science, University of Missouri, Columbia, Missouri 65211, USA. 
studies of intact luteal tissue from ewes treated with human chorionic gonadotrophin (hCG) or $\mathrm{LH}$ are also consistent with the hypothesis that small luteal cells can differentiate into large luteal cells (Gamboni et al., 1984; Niswender et al., 1985; Farin et al., 1988).

The Booroola Merino is a highly prolific breed of sheep. The enhanced prolificacy of the Booroola is controlled by a major gene, known as the F-gene, whose action is to increase ovulation rate (Davis et al., 1982). Booroola ewes which bear the wild-type or ++ genotype have an ovulation rate comparable to that found in most other breeds of sheep (i.e. 1-2 ovulations per cycle). In contrast, Booroola ewes homozygous for the F-gene (i.e. FF) have a mean ovulation rate of $\geq 5$ ovulations per cycle (for review see Bindon, 1984). Oestrogen-secreting follicles found in FF ewes are considerably smaller after treatment with cloprostenol than those seen in ++ ewes $(2.9 \pm 0.1 \mathrm{~mm}$ diameter vs $5.1 \pm 0.3 \mathrm{~mm}$ diameter, respectively; McNatty et al., 1986). Similarly, there are fewer granulosa cells present in follicles from FF ewes compared to follicles from ++ ewes $\left(\sim 1 \times 10^{6}\right.$ vs $\sim 4 \times 10^{6}$ cells per oestrogen-secreting follicle, respectively; McNatty et al., 1986). However, the total number of granulosa cells in oestrogen-secreting follicles per ovary is comparable for ewes of both genotypes and is approximately $5.4 \times 10^{6}$ cells. Circulating concentrations of oestradiol do not differ between ewes of the FF and ++ genotypes (McNatty et al., 1986).

The purpose of the first experiment was to compare peripheral concentrations of progesterone, and individual and total luteal weights at different stages of the reproductive cycle in $\mathrm{FF}$ and ++ ewes. If the population of large luteal cells found in sheep CL arises only from granulosa cells of the preovulatory follicle, then the FF Booroola ewe which has $20-33 \%$ as many granulosa cells per preovulatory follicle may have $20-33 \%$ of the number of large luteal cells in the resulting $\mathrm{CL}$ compared with those from ewes with the ++ genotype. Therefore, a second experiment was conducted to compare the numbers of luteal cells in FF and ++ Booroola Merino ewes on Day 10 of the reproductive cylce.

\section{Materials and Methods}

Booroola Merino ewes demonstrating normal oestrous cycles were housed at the Wallaceville Animal Research Centre, Upper Hutt, New Zealand. Oestrous activity was monitored using vasectomized rams fitted with marking harnesses. Genotype was based on pedigree and confirmed by regular, annual laparoscopic determination of ovulation rate. Ewes with the ++ genotype were never observed to have ovulated more than 2 follicles at a single oestrus, whereas those with the FF genotype had ovulated $\geq 5$ follicles at least once annually since 18 months of age. For Exp. 1, ovaries were collected from ewes on Day $4(\mathrm{~N}=8$ for each genotype), $10(\mathrm{~N}=5$ for each genotype $)$ and $12(\mathrm{~N}=8$ for each genotype) of the oestrous cycle. For Exp. 2, CL were collected from 5 ewes each in the FF and ++ groups on Day 10 of the cycle. All CL were dissected from the surrounding ovarian stroma, weighed and placed in Modified Eagle's Medium supplemented with Earl's salts, $20 \mathrm{~mm}$-Hepes buffer and $0.1 \%$ bovine serum albumin. For Exp. 2 the volume of each corpus luteum was determined and a central slice was removed and fixed in a solution of $4 \%$ glutaraldehyde $-0.1 \mathrm{M}$-cacodylate buffer containing $6 \%$ sucrose $(\mathrm{pH} 7 \cdot 4)$. After fixation, the slice was cut into 6 equally-sized tissue blocks and processed for electron microscopy. The cellular composition of one corpus luteum selected at random from each ewe was determined by morphometric analysis (Farin et al., 1986). Morphometric and steroid data were analysed by two-way analysis of variance.

In both experiments a single blood sample was collected at the time of collection of the CL and analysed for progesterone content (McNatty et al., 1981). The limit of detection of progesterone in plasma was $0.2 \mathrm{ng} / \mathrm{ml}$ and the intra-assay coefficient of variation was $<8 \%$.

\section{Results}

\section{Experiment 1}

The mean ovulation rate in the FF ewes ranged from 5.3 to 6.2 compared to 1.5 to 1.8 $(P<0.01)$ in the ++ ewes, confirming the expected genotypic difference in ovulation rate (Table 1). Plasma concentrations of progesterone and total luteal weight were not different between the two groups of ewes on any of the days studied. The weight of individual CL was less $(P<0.01)$ in the FF ewes (Table 1). 
Table 1. Number of corpora lutea, peripheral progesterone concentrations and luteal weights in Booroola Merino ewes

\begin{tabular}{|c|c|c|c|}
\hline & Day 4 & Day 10 & Day 12 \\
\hline $\begin{array}{c}\text { Number of CL } \\
++ \text { ewes } \\
\text { FF ewes } \\
\text { Probability }\end{array}$ & $\begin{array}{r}1.5 \pm 0.3 \quad(8) \\
5.5 \pm 0.5 \quad(8) \\
<0.01\end{array}$ & $\begin{array}{r}1.8 \pm 0.3 \\
6.2 \pm 0.7 \\
<0.01\end{array}$ & $\begin{array}{r}1.8 \pm 0.3 \\
5.3 \pm 0.4 \\
<0.01\end{array}$ \\
\hline $\begin{array}{l}\text { Plasma progesterone c } \\
++ \text { ewes } \\
\text { FF ewes } \\
\text { Probability }\end{array}$ & $\begin{array}{l}(\mathrm{ng} / \mathrm{ml}) \\
0.5 \pm 0 \cdot 1 \\
0.7 \pm 0 \cdot 1 \\
\mathrm{NS}\end{array}$ & $\begin{array}{c}1 \cdot 7 \pm 0.3 \\
2 \cdot 3 \pm 0.5 \\
\text { NS }\end{array}$ & $\begin{array}{c}2.4 \pm 0.3 \\
1.7 \pm 0.2 \\
\text { NS }\end{array}$ \\
\hline $\begin{array}{l}\text { Mean CL weight (g) } \\
++ \text { ewes } \\
\text { FF ewes } \\
++/ \text { FF ratio } \\
\text { Probability }\end{array}$ & $\begin{array}{c}0.28 \pm 0.04 \\
0.11 \pm 0.01 \\
2.5 \\
<0.01\end{array}$ & $\begin{array}{c}0.53 \pm 0.04 \\
0.16 \pm 0.02 \\
3.3 \\
<0.01\end{array}$ & $\begin{array}{c}0.59 \pm 0.03 \\
0.17 \pm 0.02 \\
3.5 \\
<0.01\end{array}$ \\
\hline $\begin{array}{l}\text { Total luteal weight }(\mathrm{g}) \\
++ \text { ewes } \\
\text { FF ewes } \\
\text { Probability }\end{array}$ & $\begin{array}{c}0.41 \pm 0.10 \\
0.60 \pm 0.10 \\
\text { NS }\end{array}$ & $\begin{array}{c}0.98 \pm 0.16 \\
0.96 \pm 0.04 \\
\text { NS }\end{array}$ & $\begin{array}{c}1.01 \pm 0.08 \\
0.87 \pm 0.17 \\
\text { NS }\end{array}$ \\
\hline
\end{tabular}

Values are mean \pm s.e.m. for the no. of ewes indicated in parentheses.

NS $=$ not significant

\section{Experiment 2}

Table 2 contains data regarding the average luteal weight in the two groups and the number of nuclei counted for each cell type. The numbers of steroidogenic and non-steroidogenic cell types were less $(P<0.01)$ in luteal tissue collected from the FF group of ewes than in tissue from ++ ewes on a per corpus luteum basis (Table 3). However, if cell numbers were expressed per gram of luteal tissue there was no difference between the two groups. Likewise, the volume density of each cell type was not different between luteal tissue obtained from the two groups of ewes (Table 4). Finally, there was no difference in the volume or diameter of any cell type between the two groups of ewes (Table 4).

Table 2. Summary of luteal weight and number of nuclei counted for Exp. 2

\begin{tabular}{lrr}
\hline & \multicolumn{2}{c}{$\begin{array}{l}\text { Booroola } \\
\text { genotype }\end{array}$} \\
\cline { 2 - 3 } & ++ & FF \\
\hline No. of ewes & 5 & 5 \\
No. of nuclei & & \\
$\quad$ Small luteal cells & 127 & 100 \\
Large luteal cells & 62 & 75 \\
Fibroblasts & 112 & 145 \\
Capillary endothelial/pericytes & 251 & 250 \\
\hline
\end{tabular}

\section{Discussion}

The purpose of this study was to determine whether the number of large steroidogenic luteal cells in FF Booroola ewes was $20-33 \%$ of those in ++ ewes (McNatty et al., 1986). This result was 
Table 3. Numbers (mean \pm s.e.m.) of different cell types in CL of Booroola Merino ewes

\begin{tabular}{|c|c|c|c|c|}
\hline \multirow[b]{2}{*}{ Type of cell } & \multicolumn{2}{|c|}{$\begin{array}{l}\text { No. of cells/CL } \\
\quad\left(\times 10^{-6}\right)\end{array}$} & \multicolumn{2}{|c|}{$\begin{array}{l}\text { No. of cells/g } \\
\left(\times 10^{-6}\right)\end{array}$} \\
\hline & ++ & FF & ++ & FF \\
\hline $\begin{array}{l}\text { Total steroidogenic } \\
\text { cells } \\
\text { Small luteal cells } \\
\text { Large luteal cells }\end{array}$ & $\begin{array}{c}107 \pm 10 \\
77 \pm 11 \\
30 \pm 6\end{array}$ & $\begin{array}{l}31 \pm 3^{\mathrm{a}} \\
18 \pm 2^{\mathrm{a}} \\
13 \pm 4^{\mathrm{b}}\end{array}$ & $\begin{array}{r}216 \pm 23 \\
156 \pm 20 \\
61 \pm 13\end{array}$ & $\begin{array}{r}209 \pm 17 \\
127 \pm 23 \\
82 \pm 13\end{array}$ \\
\hline $\begin{array}{l}\text { Fibroblasts } \\
\text { Capillary endothelial/ } \\
\text { pericytes } \\
\text { Eosinophils }\end{array}$ & $\begin{aligned} 69 & \pm 11 \\
147 & \pm 37 \\
4 & \pm 2\end{aligned}$ & $\begin{array}{l}26 \pm 3^{a} \\
40 \pm 3^{b}\end{array}$ & $\begin{aligned} 137 & \pm 15 \\
285 & \pm 54 \\
9 & \pm 6\end{aligned}$ & $\begin{array}{c}168 \pm 11 \\
269 \pm 21 \\
0\end{array}$ \\
\hline Total cell number & $326 \pm 46$ & $97 \pm 7^{\mathrm{a}}$ & $647 \pm 57$ & $645 \pm 35$ \\
\hline
\end{tabular}

${ }^{a}$ Values are different $(P<0.01)$.

bValues are different $(P<0.05)$

Table 4. Mean ( \pm s.e.m.) luteal cell volumes, diameters and volume densities in Booroola Merino ewes with ++ and FF genotypes

\begin{tabular}{|c|c|c|}
\hline Cell type & ++ ewes & FF ewes \\
\hline $\begin{array}{l}\text { Small luteal cells } \\
\text { Volume }\left(\mu \mathrm{m}^{3} \times 10^{-3}\right) \\
\text { Diameter }(\mu \mathrm{m}) \\
\text { Volume density }(\%)\end{array}$ & $\begin{array}{r}1.5 \pm 0.3 \\
14.1 \pm 0.9 \\
22.6 \pm 3.3\end{array}$ & $\begin{array}{r}1.5 \pm 0.1 \\
14.2 \pm 0.4 \\
18.7 \pm 3.5\end{array}$ \\
\hline $\begin{array}{l}\text { Large luteal cells } \\
\text { Volume }\left(\mu \mathrm{m}^{3} \times 10^{-3}\right) \\
\text { Diameter }(\mu \mathrm{m}) \\
\text { Volume density }(\%)\end{array}$ & $\begin{array}{r}6 \cdot 8 \pm 1 \cdot 6 \\
23 \cdot 0 \pm 1 \cdot 8 \\
33.8 \pm 2.8\end{array}$ & $\begin{array}{r}4 \cdot 4 \pm 0.6 \\
20 \cdot 2 \pm 0.9 \\
33 \cdot 6 \pm 2.5\end{array}$ \\
\hline $\begin{array}{c}\text { Total steroidogenic cells } \\
\text { Volume density }(\%)\end{array}$ & $56.4 \pm 3.6$ & $52 \cdot 4 \pm 3 \cdot 2$ \\
\hline $\begin{array}{l}\text { Fibroblasts } \\
\text { Volume }\left(\mu \mathrm{m}^{3} \times 10^{-3}\right) \\
\text { Diameter }(\mu \mathrm{m}) \\
\text { Volume density }(\%)\end{array}$ & $\begin{array}{r}0.6 \pm 0.1 \\
10.1 \pm 0.4 \\
7.5 \pm 1 \cdot 1\end{array}$ & $\begin{array}{l}0.5 \pm 0.1 \\
9.6 \pm 0.5 \\
7.9 \pm 1.3\end{array}$ \\
\hline $\begin{array}{l}\text { Capillary endothelial/peric } \\
\text { Volume }\left(\mu \mathrm{m}^{3} \times 10^{-3}\right) \\
\text { Diameter }(\mu \mathrm{m}) \\
\text { Volume density }(\%)\end{array}$ & $\begin{aligned} \text { es } \\
0 \cdot 4 \pm 0 \cdot 0 \\
8 \cdot 8 \pm 0 \cdot 2 \\
14 \cdot 1 \pm 2 \cdot 1\end{aligned}$ & $\begin{array}{r}0.4 \pm 0.0 \\
8.9 \pm 0.2 \\
14.7 \pm 0.7\end{array}$ \\
\hline $\begin{array}{l}\text { Vascular space } \\
\text { Volume density }(\%)\end{array}$ & $3 \cdot 7 \pm 1 \cdot 0$ & $4 \cdot 8 \pm 0.2$ \\
\hline $\begin{array}{l}\text { Eosinophils } \\
\text { Volume density (\%) }\end{array}$ & $0.1 \pm 0.0$ & 0 \\
\hline $\begin{array}{l}\text { Matrix } \\
\text { Volume density (\%) }\end{array}$ & $17 \cdot 1 \pm 1 \cdot 2$ & $26.6 \pm 7.9$ \\
\hline $\begin{array}{l}\text { Other } \\
\text { Volume density (\%) }\end{array}$ & $4 \cdot 7 \pm 0.4$ & $4 \cdot 4 \pm 0 \cdot 3$ \\
\hline
\end{tabular}


anticipated since there are approximately 3-5 times more granulosa cells per follicle in ++ Booroola ewes. There were significantly $(P<0.01)$ fewer large steroidogenic luteal cells in the FF Booroola ewes, $43 \%$ of the number of large cells in ++ ewes. There were $29 \%$ as many total steroidogenic cells and $23 \%$ as many small steroidogenic luteal cells in the FF as in the ++ ewes. Therefore, although these results may support the concept that follicular granulosa cells develop into large steroidogenic luteal cells, this point cannot be unequivocally made. It should also be noted that it was not possible to determine the number of granulosa cells in an individual follicle and the number of large luteal cells following ovulation of the same follicle. Therefore, the comparisons are all based on published data regarding granulosa cell numbers.

At $48 \mathrm{~h}$ after luteolysis induced by prostaglandin F-2 $\alpha$ on Day 10 of the oestrous cycle presumptive preovulatory follicles of FF and ++ ewes have been reported to contain approximately 2 and $7 \times 10^{6}$ granulosa cells (McNatty et al., 1986), while the CL contained 13 and $30 \times 10^{6}$ large steroidogenic luteal cells, respectively. This would suggest 3-4 cell divisions during early luteal formation if granulosa cells are the source of large steroidogenic luteal cells. Granulosa cells are known to divide during luteinization around the periovulatory period (McClellan et al., 1975).

This experiment afforded the opportunity to compare data from Booroola Merino ewes with those obtained in two previous studies with Corriedale (O'Shea et al., 1986) and 'western range ewes' (predominantly Corriedale $\times$ Columbia; Farin et al., 1986) in which morphometric analysis of luteal cells was performed. In general, there was good agreement between the data of Rodgers et al. (1984), O'Shea et al. (1986) and Farin et al. (1986) in volume densities, cell numbers per corpus luteum and cell volume in ewes of similar breed. The only tendencies for differences were that Rodgers et al. (1984) and O'Shea et al. (1986) reported approximately $9-11 \times 10^{6}$ large steroidogenic luteal cells per corpus luteum compared with about $18 \times 10^{6}$ reported by Farin et al. (1986). Farin et al. (1986) also reported approximately $30 \times 10^{6}$ fibroblasts while Rodgers et al. (1984) reported $43 \times 10^{6}$ and O'Shea et al. (1986) found about $17 \times 10^{6}$. The current study utilized Booroola Merino ewes and three major differences were apparent when the data were compared to those obtained in Corriedale or 'western range ewes'. First, in Booroola Merino ++ ewes there were slightly more small steroidogenic luteal cells $\left(\sim 77\right.$ vs $\left.50 \times 10^{6}\right)$, more large steroidogenic luteal cells $\left(7-22\right.$ vs $\left.30 \times 10^{6}\right)$ which had a smaller volume $\left(15-20 v s 7 \mu \mathrm{m}^{-3}\right)$, and increased numbers of fibroblasts ( 69 vs $15-43 \times 10^{6}$ per corpus luteum). Since the study by Farin et al. (1986) and the current study were performed using the same methods and criteria for characterization of the different cell types, it seems probable that the differences are due to differences between breeds rather than methodological differences.

It seems clear from the data obtained in this study that the only difference in CL from the two types of Booroola Merino ewes is size. Luteal cell types from the two groups of ewes had similar volume densities, cell numbers per gram of luteal tissue, and similar cell diameters and volumes. When the total mass of luteal tissue and peripheral concentrations of progesterone were evaluated in Exp. 1 there were no differences in corpora lutea collected from the two types of ewes. The 5-6 corpora lutea in FF Booroola ewes appear to function in an identical fashion to the 1-2 corpora lutea in ++ ewes.

We thank George Davis, Invermay Agricultural Research Centre, for supplying the animals and details of their reproductive records.

\section{References}

Alila, H.W. \& Hansel, W. (1984) Origin of different cell types in the bovine corpus luteum as characterized by specific monoclonal antibodies. Biol. Reprod. 31, 1015-1025.

Bindon, B.M. (1984) Reproductive biology of the Booroola Merino sheep. Aust. J. biol. Sci. 37, 163-189.
Davis, G.H., Montgomery, G.W., Allison, A.J., Kelly, R.W. \& Bray, A.R. (1982) Segregation of a major gene influencing fecundity in progeny of Booroola sheep in New Zealand. NZ J. agric. Res. 25, 525-529.

Deane, H.W., Hay, M.F., Moor, R.M., Rowson, L.E.A. \& Short, R.V. (1966) The corpus luteum of the sheep: relationships between morphology and function 
during the oestrous cycle. Acta endocr., Copenh. 51, 245-263.

Donaldson, L. \& Hansel, W. (1965) Histological study of bovine corpora lutea. J. Dairy Sci. 48, 905-909.

Farin, C.E., Moeller, C.L., Sawyer, H.R., Gamboni, F. \& Niswender, G.D. (1986) Morphometric analysis of cell types in the ovine corpus luteum through the estrous cycle. Biol. Reprod. 35, 1299-1308.

Farin, C.E., Moeller, C.L., Mayan, H., Gamboni, F., Sawyer, H.R. \& Niswender, G.D. (1988) Effect of LH and hCG on cell populations in the ovine corpus luteum. Biol. Reprod. 38, 4l3-422.

Fitz, T.A., Mayan, M.H., Sawyer, H.R. \& Niswender, G.D. (1982) Characterization of two steroidogenic cell types in the ovine corpus luteum. Biol. Reprod. 27, 703-711.

Gamboni, F., Fitz, T.A., Hoyer, P.B., Wise, M.E., Mayan, M.H. \& Niswender, G.D. (1984) Effect of human chorionic gonadotropin on induced ovine corpora lutea during the anestrous season. Dom. Anim. Endocr. 1, 79-88.

Hoyer, P.B. \& Niswender, G.D. (1985) Regulation of steroidogenesis is different in the two types of ovine luteal cells. Can. J. Physiol. Pharm. 63, 240-248.

McClellan, M.C., Diekman, M.A., Abel, J.H., Jr \& Niswender, G.D. (1975) Luteinizing hormone, progesterone and morphological development of normal and superovulated corpora lutea in sheep. Cell Tiss. Res. 164, 291-307.

MeNatty, K.P., Gibb, M., Dobson, C., Thurley, D.C. \& Findlay, J.K. (1981) Changes in the concentrations of gonadotrophic and steroidal hormones in the antral fluid of ovarian follicles throughout the oestrous cycle of the sheep. Aust. J. biol. Sci. 34, 67-80.

McNatty, K.P., Lun, S., Heath, D.A., Ball, K., Smith, P., Hudson, N.L., McDiarmid, J., Gibb, M. \& Henderson, K.M. (1986) Differences in ovarian activity between Booroola $\times$ Merino ewes which were homozygous, heterozygous and non-carriers of a major gene influencing their ovulation rate. J. Reprod. Fert. 77, 193-205.

Niswender, G.D., Schwall, R.H., Fitz, T.A., Farin, C.E. \& Sawyer, H.R. (1985) Regulation of luteal function in domestic ruminants: new concepts. Recent Prog. Horm. Res. 41, 101-151.

O'Shea, J.D. (1987) Heterogeneous cell types in the corpus luteum of sheep, goats and cattle. J. Reprod. Fert., Suppl. 34, 71-85.

O'Shea, J.D., Cran, D.G. \& Hay, M.F. (1979) The small luteal cell of the sheep. J. Anat. 128, 239-251.

O'Shea, J.D., Cran, D.G. \& Hay, M.F. (1980) Fate of the theca interna following ovulation in the ewes. Cell Tiss. Res. 210, 302-319.

O'Shea, J.D., Rodgers, R.J. \& Wright, P.J. (1986) Cellular composition of the sheep corpus luteum in the mid- and late luteal phases of the oestrous cycle. $J$. Reprod. Fert. 76, 685-691.

Rodgers, J.D., O'Shea, J.D. \& Bruce, N.W. (1984) Morphometric analysis of the cellular composition of the ovine corpus luteum. J. Anat. 138, 757-769.

Received 13 December 1989 